\title{
WORK ABILITY ASSESSMENT IN A PATIENT WITH WILSON'S DISEASE
}

\author{
Martin B. POPEVIĆ ${ }^{1}$, Gordana KISIĆ ${ }^{2}$ Milenko ĐUKIĆ², and Petar BULAT ${ }^{1}$ \\ University of Belgrade School of Medicine ${ }^{1}$, Serbian Institute for Occupational Health ${ }^{2}$, Belgrade, Serbia \\ Received in April 2011 \\ CrossChecked in May 2011 \\ Accepted in May 2011
}

\begin{abstract}
Wilson's disease (WD) is a rare, progressive autosomal recessive disorder characterised by impaired transport and excessive accumulation of copper in the liver, brain, and other tissues. The disease is diagnosed based on clinical manifestations and screening tests results. Work ability assessment of patients with WD is based on the analysis of liver, kidney, neurological, and cognitive impairments, and takes into account patient's level of education.

This article presents a case with a 48-year-old male patient, who was admitted for work ability assessment due to polymorphic symptoms. The patient had been working as a salesman for 28 years. A detailed interview and examination by occupational health and other medical specialists revealed that the patient had been suffering from Wilson's disease from the age of 13 , and had now developed hepatic manifestations (compensated liver cirrhosis with portal hypertension), neurological manifestations (dystonia, dysarthria, muscle weakness, vertigo), and psychiatric manifestations (depression, insomnia, cognitive impairment) of the disease, including problems partially caused by long-lasting treatment with copper chelating agents (neurological and haematological manifestations). There were no ocular manifestations of Wilson's disease (Kayser-Fleischer rings or sunflower cataract).

The patient was assessed as having drastically diminished general work ability, dominantly due to neurological and psychiatric impairments caused by Wilson's disease.
\end{abstract}

KEY WORDS: chelation therapy, cognitive impairment, copper, depression, disability evaluation, Dpenicillamine, dysarthria, dystonia, insomnia, Kayser-Fleischer rings, liver cirrhosis, muscle weakness, portal hypertension, psychiatric disorders, vertigo

Wilson's disease (WD) is a progressive autosomal recessive disorder characterised by impaired copper transport and excessive accumulation of copper in the liver, brain, and other tissues. It has been named after S. A. Kinnier Wilson, who first described it in detail in Brain in 1912, addressing both pathological and clinical manifestations (1).

Wilson's disease is caused by a mutation in the ATP7B gene, located in chromosome 13, which encodes a Copper-Binding P-type ATPase, expressed dominantly in the liver cells and vital for the transmembrane transport of copper (2-5). Impaired function of this enzyme leads to decreased excretion of copper from the liver cells into bile. Consequently, copper accumulates in the liver cells, disrupting their structure and function. In addition, it is released into the blood stream and transported to other target organs such as the brain, kidneys, and eyes, where it also accumulates and does damage.

It is a rare disease, with average prevalence of 30 per million population $(6,7)$. Its diagnosis is based on clinical manifestations and screening test results. Clinical manifestations include liver disease (hepatitis, cirrhosis, liver failure), progressive neurological 
disorder (dystonia, tremor, dysphagia, dysarthria), and a psychiatric illness (depression, cognitive and emotional impairment) $(7,8)$. Screening tests include 24-h urine copper excretion, serum and urine copper levels, ceruloplasmin serum level, and eye examination for Kayser-Fleischer ring with a slit lamp. The definitive diagnostic test is quantitative analysis of copper in a dry liver tissue sample obtained by percutaneous liver biopsy (9).

Work ability assessment of patients with WD is based on the analysis of liver, kidney, neurological, and cognitive impairment, and takes into account patient's level of education (10).

\section{CASE REPORT}

A 48-year old male patient D. M. was admitted for work ability assessment to the Serbian Institute for Occupational Health. His main symptoms were weakness in arms and legs, tremor, general fatigue, insomnia, headache, anxiety, blurry vision, forgetfulness, and vertigo.

Patient's history revealed that he had a severe hepatitis-like liver disease at the age of 10 , that he was diagnosed Wilson's disease at the age of 13 , and that he had been treated with D-penicillamine from the age of 14. The first administration of D-penicillamine worsened the symptoms and led to high fever and intense neurological problems, including a weakness of the left arm and leg, dysphagia, and dysarthria. Withdrawal of D-penicillamine relieved the symptoms, but some neurological issues remained. Since then, the patient had been monitored closely, as he continued treatment with D-penicillamine $(500 \mathrm{mg}$ three times a day) and pyridoxine oral preparations (20 $\mathrm{mg}$ three times a day). Over the last three years, his health got worse, especially the neurological problems, and he developed new psychiatric and vision problems (blurry vision, impaired vision of the left eye). $\mathrm{He}$ denied having any new manifestations of the liver disease, but he had been told at earlier examinations that he had enlarged liver and spleen. The patient reported no other co-morbidities of interest or allergies; he did not smoke and did not drink alcohol.

Family history revealed that his mother had died of liver tumour, but none of his close relatives suffered from other chronic illnesses.

Occupational history showed that the patient had finished primary school, but could not pursue further education, except basic vocational training for a salesperson, due to a "learning disability" to use his own words. He had been selling alcoholic and nonalcoholic drinks for 28 years. The initial clinical examination performed by an occupational health specialist revealed that the patient was obese, had normal vital signs, distended abdomen painful on palpation, and signs of enlarged liver at the level of the right rib arch. Upper extremities showed signs of involuntary tremor, and lower legs were swollen and skin hyperpigmented bilaterally.

To confirm previous WD diagnosis, we performed screening tests. Complete blood count was normal save for a mild platelet deficiency $\left(145 \times 10^{9} \mathrm{~L}^{-1}\right.$; reference interval $158 \times 10^{9} \mathrm{~L}^{-1}$ to $424 \times 10^{9} \mathrm{~L}^{-1}$ ). Liver function test was also normal, save for higher direct bilirubin $\left(5.9 \mu \mathrm{mol} \mathrm{L}^{-1}\right.$; reference threshold $\left.<3.4 \mu \mathrm{mol} \mathrm{L}^{-1}\right)$ and total bilirubin $\left(22.3 \mu \mathrm{mol} \mathrm{L}^{-1}\right.$; reference interval $5.1 \mu \mathrm{mol} \mathrm{L}^{-1}$ to $20.5 \mu \mathrm{mol} \mathrm{L}^{-1}$ ). Serum ceruloplasmin levels were significantly lower than normal $\left(0.02 \mathrm{~g} \mathrm{~L}^{-1}\right.$; reference interval $0.2 \mathrm{~g} \mathrm{~L}^{-1}$ to $\left.0.6 \mathrm{~g} \mathrm{~L}^{-1}\right)$. Serum copper level was lower than normal $\left(3.3 \mu \mathrm{mol} \mathrm{L}-1\right.$; reference interval $10 \mu \mathrm{mol} \mathrm{L}^{-1}$ to $22 \mu \mathrm{mol} \mathrm{L}{ }^{-1}$ ), and 24-h urine copper was $6.51 \mu \mathrm{mol}$ (reference threshold $<0.6 \mu \mathrm{mol}$ ).

Abdominal ultrasound confirmed enlarged liver (cephalic-caudal diameter of the right lobe was $16 \mathrm{~cm}$ ) in the state of compensated cirrhosis and enlarged spleen $(15.5 \mathrm{~cm} \times 6 \mathrm{~cm})$ with signs of portal hypertension.

Detailed neurological examination showed spasmodic dystonia and muscle weakness of the left arm, weakness and slower reflexes of the left leg, positive Romberg test, and severe dysarthria. On MRI, T2-weighted images revealed hyperintensities in the region of tegmentum mesencephali and putamen bilaterally. Cortical and subcortical reduction changes were also seen, as well as microvascular ischemic lesions in the region of centrum semiovale.

A detailed psychological and psychiatric examination showed borderline intelligence ( $\mathrm{IQ}=78)$, with indicators of secondary cognitive deficit. Cognitive functions were substantially diminished. There were signs of emotional lability with autoagressive behaviour. There were no data available that would indicate any cognitive or emotional issues during early childhood, that is, before the first manifestations of the illness came through or before the initial D-penicillamine treatment.

Eye examination with a slit lamp showed no presence of Kayser-Fleischer rings, but there were 
signs of hypermetropia, presbyopia, and anysometropia. The difference between the left and the right eye was more than 3 dioptres.

Dermatological examination showed signs of stasis dermatitis due to compromised peripheral circulation in the lower extremities.

\section{DISCUSSION}

Initial clinical manifestations of Wilson's disease can involve neurological (in $40 \%$ to $60 \%$ of the patients) or liver function impairments (in $40 \%$ to $50 \%$ of the patients) (7). Earlier onset of the disease is more often seen in patients with liver disease (11.4 years vs. 18.9 years in patients with neurological forms) (11). When diagnosed WD at the age of 13 , our patient had acute hepatitis-like symptoms and signs. They seem to appear first in over $25 \%$ of WD patients (12). Current liver function in our patient is also very common and involves progressive hepatic cirrhosis with enlarged liver and spleen and signs of portal hypertension. This level of liver disease alone is a contraindication for any kind of work that involves lifting heavy loads and dealing with hepatotoxic chemical agents (10).

Neurological impairment in WD can be classified as: (a) an akinetic-rigid syndrome similar to Parkinson's disease, (b) pseudosclerosis dominated by tremor, (c) ataxia, and (d) a dystonic syndrome (13). Our patient mostly had dystonic manifestations, with some elements of pseudosclerosis.

Characteristic MRI changes in WD patients include lesions in the putamen, globus pallidus, caudate, thalamus, midbrain, pons, and cerebellum as well as cortical atrophy and white matter changes. In general, these lesions show high T2 and low T1 signal intensity (15). Our patient's MRI showed hyperintensities in the region of tegmentum mesencephali and putamen bilaterally. In addition, we observed cortical and subcortical reduction changes, which are in line with MRI changes characteristic for WD.

Neurological manifestations of Wilson's disease usually include resting or postural tremor, dysarthria ( 85 to $97 \%$ of those with neurologic WD have this sign) (15), dystonia ( $11 \%$ to $65 \%$ of WD patients) (16), dysphagia, drooling, headaches, and insomnia (9). Our patient had dominantly suffered from spasmodic dystonia of the left arm and leg and from severe dysarthria, vertigo, headaches, and insomnia.
In terms of work ability, this level of neurological impairment in conjunction with specific MRI changes is contraindicated for any kind of work, due to tremor, muscle weakness, and speech problems, but most of all, due to progressive and irreversible nature of the disease itself (17).

Psychiatric manifestations like depression, personality changes, and cognitive impairment are present in $20 \%$ to $65 \%$ of patients with WD, especially in those with dominant neurological form the disease (12). Psychiatric examination of our patient showed signs of emotional lability with autoagressive behaviour, borderline intelligence, and diminished cognitive functions. These characteristics alone indicate work disability for all jobs that include psychological or physical strain.

Kayser-Fleischer (KF) rings are very common in patients with neurological and psychiatric manifestations of Wilson's disease, but our patient had never had them. Ross et al. (18) have also reported about the absence of Kayser-Fleischer rings in patients with WD (18).

One of the basic aims of medical treatment of WD is to eliminate excess copper from the body and to prevent its further accumulation. In 1956, John Walshe (19) introduced D-penicillamine as a successful copper chelating agent. D-penicillamine stimulates urinary excretion of copper and promotes the synthesis of metallothionein, which in turn prevents tissue accumulation of copper. D-penicillamine is still one of the most important medications in the treatment of WD, but its wide use has shown some downsides. Initial high doses of D-penicillamine can further impair the neurological function of WD patients, and this impairment has been reported to persist in as many as $50 \%$ of patients after stopping D-penicillamine treatment $(7,20)$. These findings are in compliance with our patient's history, as he showed worsening of neurological symptoms after the drug was introduced at the age of 14 and their persistence after it was stopped.

What is peculiar in this case is that no other medication (except pyridoxine supplementation) was included in our patient's treatment. Nowadays zinc acetate, trientine, and ammonium tetrachydromolibdate are drugs of choice if D-penicillamine shows adverse effects (9). Furthermore, receiving $1500 \mathrm{mg}$ of Dpenicillamine every day for 35 years could be one of the reasons for his progressive neurological deterioration over the past three years. 


\section{CONCLUSIONS}

Work ability assessment in patients suffering from Wilson's disease most of all depends on the level of organ impairment $(10,17)$. Our patient had initially presented with the hepatic form of WD, complicated with neurological and cognitive impairment due to adverse effects of high dose D-penicillamine treatment. These cognitive impairments may have led to learning disabilities that limited our patient's educational and occupational potentials. Due to early diagnosis and close monitoring, his liver function had been preserved for long; after 35 years with the diagnosis and 28 years of hard work, liver impairment was only at the level of compensated liver cirrhosis and portal hypertension. His neurological and psychiatric manifestations, on the other hand, had progressed far more after longterm use of high-dose D-penicillamine, and are now the main reason for his drastically diminished work ability.

Even though our patient did not have eye manifestations of WD like KF rings and sunflower cataract, non-specific vision problems (hypermetropia, presbyopia, and anysometropia), mild trombocytopenia, and compromised peripheral circulation in the lower extremities also contributed to his work disability.

\section{Acknowledgement}

This report has been approved by the Institute's Ethics Committee. The patient has consented to the publication of this report in a scientific journal, including all relevant data. This study was partly supported by the Serbian Ministry of Science and Technological Development (grant no. 175036).

\section{REFERENCES}

1. Kinnier Wilson SA. Progressive lenticular degeneration: a familial nervous disease associated with cirrhosis of the liver. Brain 1912;34:295-507.

2. Bull PC, Thomas GR, Rommens JM, Forbes JR, Cox DW. The Wilson disease gene is a putative copper transporting P-type ATPase similar to the Menkes gene. Nat Genet 1993;5:327-37.

3. Petrukhin K, Fischer SG, Piratsu M, Tanzi RE, Chernov I, Devoto M, Brzustowicz LM, Cayanis E, Vitale E, Russo JJ, Matseoane D, Boukhgalter B, Wasco W, Figus AL, Loudianos J, Cao A, Sternlieb I, Evgrafov O, Parano E, Pavone L, Warburton D, Ott J, Penchaszadeh GK, Scheinberg IH,
Gilliam TC. Mapping, cloning and genetic characterization of the region containing the Wilson disease gene. Nat Genet 1993;5:338-43

4. Yamaguchi Y, Heiny ME, Gitlin JD. Isolation and characterization of a human liver cDNA as a candidate gene for Wilson disease. Biochem Biophys Res Commun 1993;197:271-7.

5. Tanzi RE, Petrukhin K, Chernov I, Pellequer JL, Wasco W, Ross B, Romano DM, Parano E, Pavone L, Brzustowicz LM, Devoto M, Peppercorn J, Bush AI, Sternlieb I, Pirastu M, Gusella JF, Evgrafov O, Penchaszadeh GK, Honig B, Edelman IS, Soares MB, Scheinberg IH, Gilliam TC. The Wilson disease gene is a copper transporting ATPase with homology to the Menkes disease gene. Nat Genet 1993;5:34450.

6. Frydman M. Genetic aspects of Wilson's disease. J Gastroenterol Hepatol 1990;5:483-90.

7. Brewer GJ. Wilson's disease: A Clinician's Guide to Recognition, Diagnosis, and Management. Norwell (MA): Kluwer Academic Publishers; 2001.

8. Brewer GJ, Askari FK. Wilson's disease: clinical management and therapy. J Hepatol 2005;42(Suppl 1):S13-21.

9. Roberts EA, Schilsky ML. A practice guideline on Wilson disease. Hepatology 2003;37:1475-92.

10. Vidaković A. [Ocenjivanje radne sposobnosti obolelih od najčešćih bolesti jetre i žučne kesice, in Serbian]. In: Vidaković A, Pavlović MŽ, editors. Ocenjivanje radne sposobnosti. Lazarevac: Elvod print; 2003. p. 378-9.

11. Walshe JM. Wilson's disease (HLD). In: Vinken PJ, Bruyn GW, editors. Handbook of clinical neurology. Vol. 27. Amsterdam: North Holland Publishing Company; 1976. p. 379-414.

12. Pffeifer RF. Wilson's disease. Semin Neurol 2007;27:12332.

13. Ala A, Walker AP, Ashkan K, Dooley JS, Schilsky ML. Wilson's disease. Lancet 2007;369:397-408.

14. Sinha S, Taly AB, Ravishankar S, Prashanth LK, Venugopal KS, Arunodaya GR, Vasudev MK, Swamy HS. Wilson's disease: cranial MRI observations and clinical correlation. Neuroradiology 2006;48:613-21.

15. Machado A, Chien HF, Deguti MM, Cançado E, Azevedo RS, Scaff M, Barbosa ER. Neurological manifestations in Wilson's disease: Report of 119 cases. Mov Disord 2006;21:2192-6.

16. Svetel M, Kozić D, Stefanova E, Semnić R, Dragašević N, Kostić VS. Dystonia in Wilson's disease. Mov Disord 2001;16:719-23.

17. Vuletin-Lekić V. [Ocenjivanje radne sposobnosti obolelih od najčeščih neuroloških bolesti, in Serbian]. In: Vidaković A, Pavlović MŽ, editors. Ocenjivanje radne sposobnosti. Lazarevac: Elvod print; 2003. p. 427-8.

18. Ross ME, Jacobson IM, Dienstag DL, Martin JB. Late onset Wilson's disease with neurological involvement in the absence of Kayser-Fleischer rings. Ann Neurol 1985;17:4113.

19. Walshe JM. Penicillamine, a new oral therapy for Wilson's disease. Am J Med 1956;21:487-95.

20. Brewer GJ, Terry CA, Aisen AM, Hill GM. Worsening of neurologic syndrome in patients with Wilson's disease with initial penicillamine therapy. Arch Neurol 1987;44:490-3. 


\section{Sažetak \\ OCJENA RADNE SPOSOBNOSTI PACIJENTA S WILSONOVOM BOLESTI - PRIKAZ BOLESNIKA}

Wilsonova je bolest rijetka, progresivna autosomno recesivna bolest karakterizirana poremećajem transporta bakra i posljedičnim prekomjernim nakupljanjem bakra u jetri, mozgu i drugim tkivima i organima. Dijagnoza bolesti postavlja se na osnovi kliničkih manifestacija bolesti i nalaza laboratorijskih ispitivanja. Ocjena radne sposobnosti pacijenata s Wilsonovom bolesti zasniva se na analizi postojanja oštećenja i stupnja oštećenja hepatičkih, neuroloških, bubrežnih i kognitivnih funkcija, kao i na analizi stupnja obrazovanja pacijenata.

Prikazan je slučaj D. M., 48-godišnjeg pacijenta, koji je primljen zbog polimorfnih tegoba na bolničko ispitivanje radi ocjene radne sposobnosti. Pacijent je radio kao prodavač posljednjih 28 godina. Nakon detaljne anamneze i pregleda koje su obavili specijalisti medicine rada i drugi specijalisti utvrđeno je da pacijent boluje od Wilsonove bolesti od 13. godine života i da u ovom trenutku ima izražene hepatične manifestacije (kompenzirana ciroza jetre s portalnom hipertenzijom), neurološke manifestacije (distonija, dizartrija, mišićna slabost, vrtoglavica) i psihijatrijske manifestacije (depresija, nesanica, kognitivno oštećenje) Wilsonove bolesti, kao i da su prisutne tegobe djelomično uzrokovane dugotrajnom upotrebom kelatne terapije (neurološki i hematološki poremećaji). Nisu uočene karakteristične očne promjene Wilsonove bolesti (Kayser-Fleischerov prsten, katarakta u obliku suncokreta).

Ocjenom radne sposobnosti utvrđeno je da pacijent ima drastično smanjenu radnu sposobnost pretežno zbog neuroloških i psihičkih poremećaja u sklopu Wilsonove bolesti.

KLJUČNE RIJEČI: bakar, ciroza jetre, depresija, distonija, dizartrija, D-penicilamin, KayserFleischerov prsten, kelatna terapija, kognitivno oštećenje, mišićna slabost, nesanica, portalna hipertenzija, vrtoglavica

\section{CORRESPONDING AUTHOR:}

Martin B. Popević, MD

Serbian Institute for Occupational Health

Deligradska 29, 11000 Belgrade, Serbia

E-mail:popevic.martin@gmail.com 